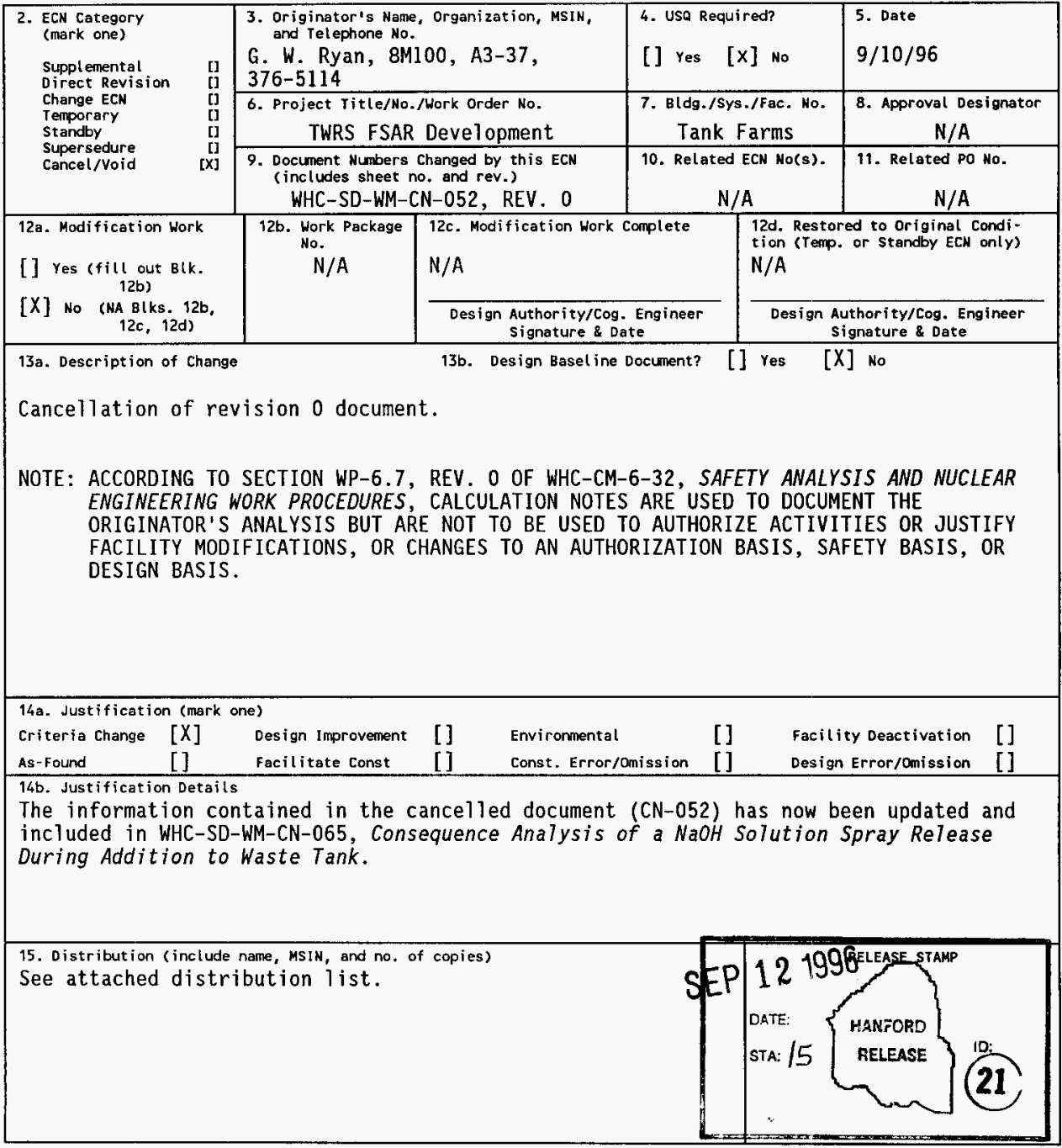




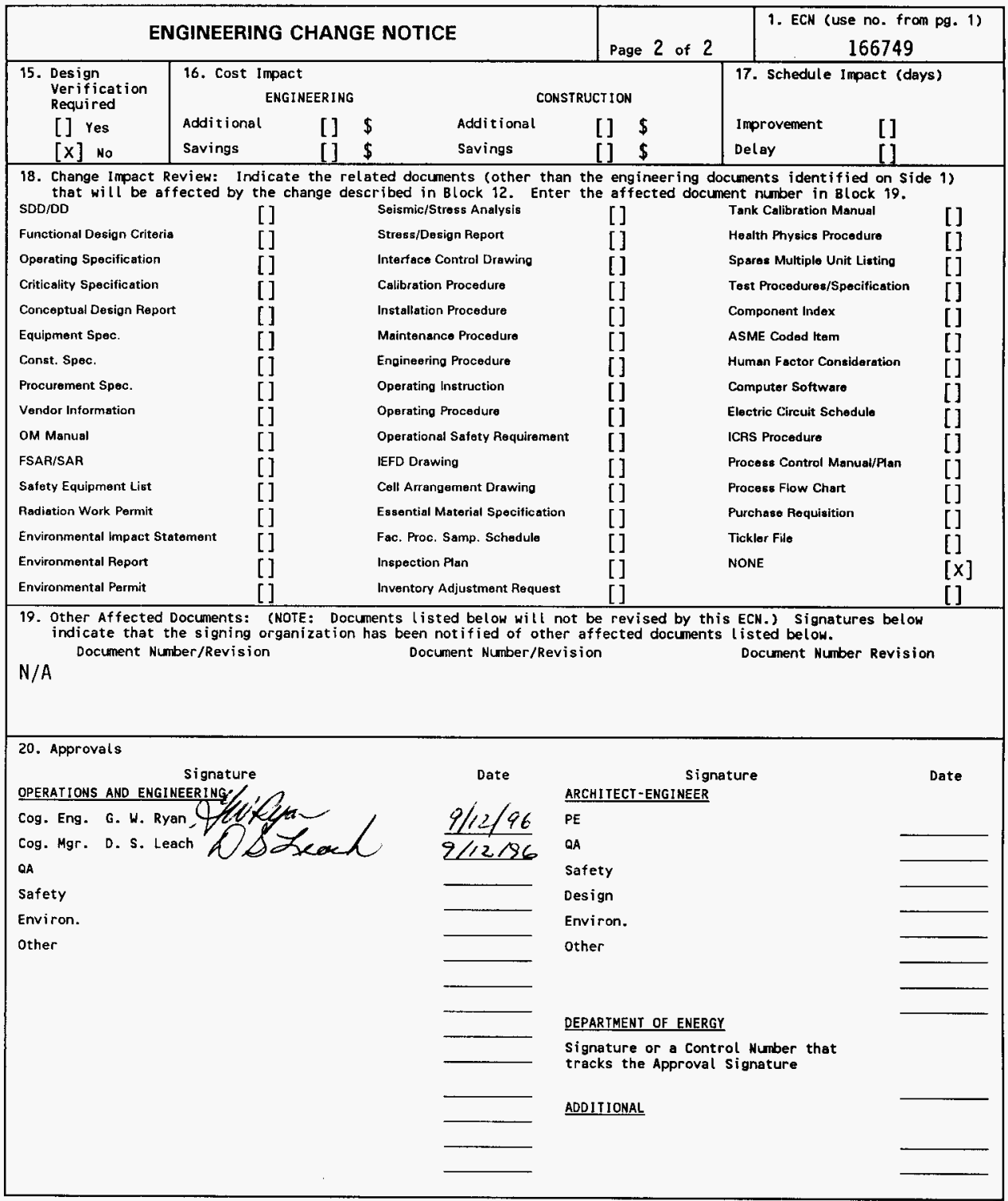




\title{
Analysis of NaOH Releases for Hanford Tank Farms
}

\author{
G. W. Ryan \\ Westinghouse Hanford Company, Richland, WA 99352 \\ U.S. Department of Energy Contract DE-AC06-87RL10930 \\ EDT/ECN: 166749 \\ UC: 510 \\ Org Code: 8 M100 \\ Charge Code: N1FC3 \\ B\&R Code: EW3120071 \\ Total Pages: 1 \\ Key Words: caustic spray leak, $\mathrm{NaOH}$, sodium hydroxide, caustic \\ addition, TWRS, tank farms \\ Abstract: The information contained in the cancelled document is now \\ located in the document: Consequence Analysis of a $\mathrm{NaOH}$ Solution Spray \\ Release During Addition to Waste Tank, WHC-SD-WM-CN-065.
}

\footnotetext{
TRADEMARK DISCLAIMER. Reference herein to any specific cormercial product, process, or service by trade name, tradenark, manufacturer, or otherwise, does not necessarily constitute or imply its endorsement, recommendation, or favoring by the United States Government or any agency thereof or its contractors or subcontractors.

Printed in the United States of America. To obtain copies of this document, contact: WHC/BCS Document Control Services, P.O. Box 1970, Mailstop H6-08, Richland WA 99352, Phone (509) 372-2420; Fax (509) 376-4989.
}
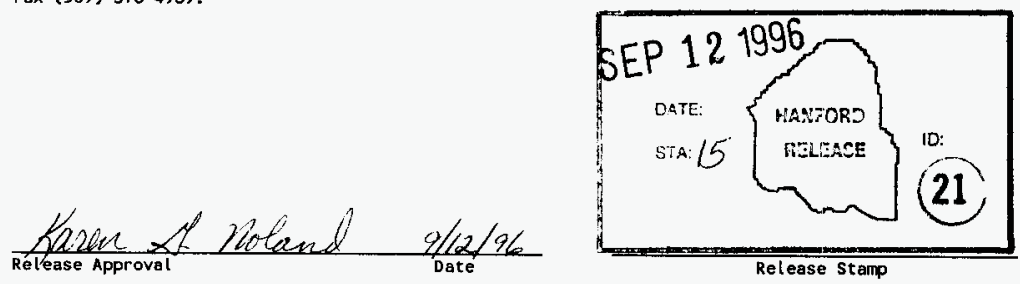

\section{Approved for Public Release}




\section{RECORD OF REVISION}

(2) Title

Analysis of $\mathrm{NaOH}$ Releases for Hanford Tank Farms

CHANGE CONTROL RECORD

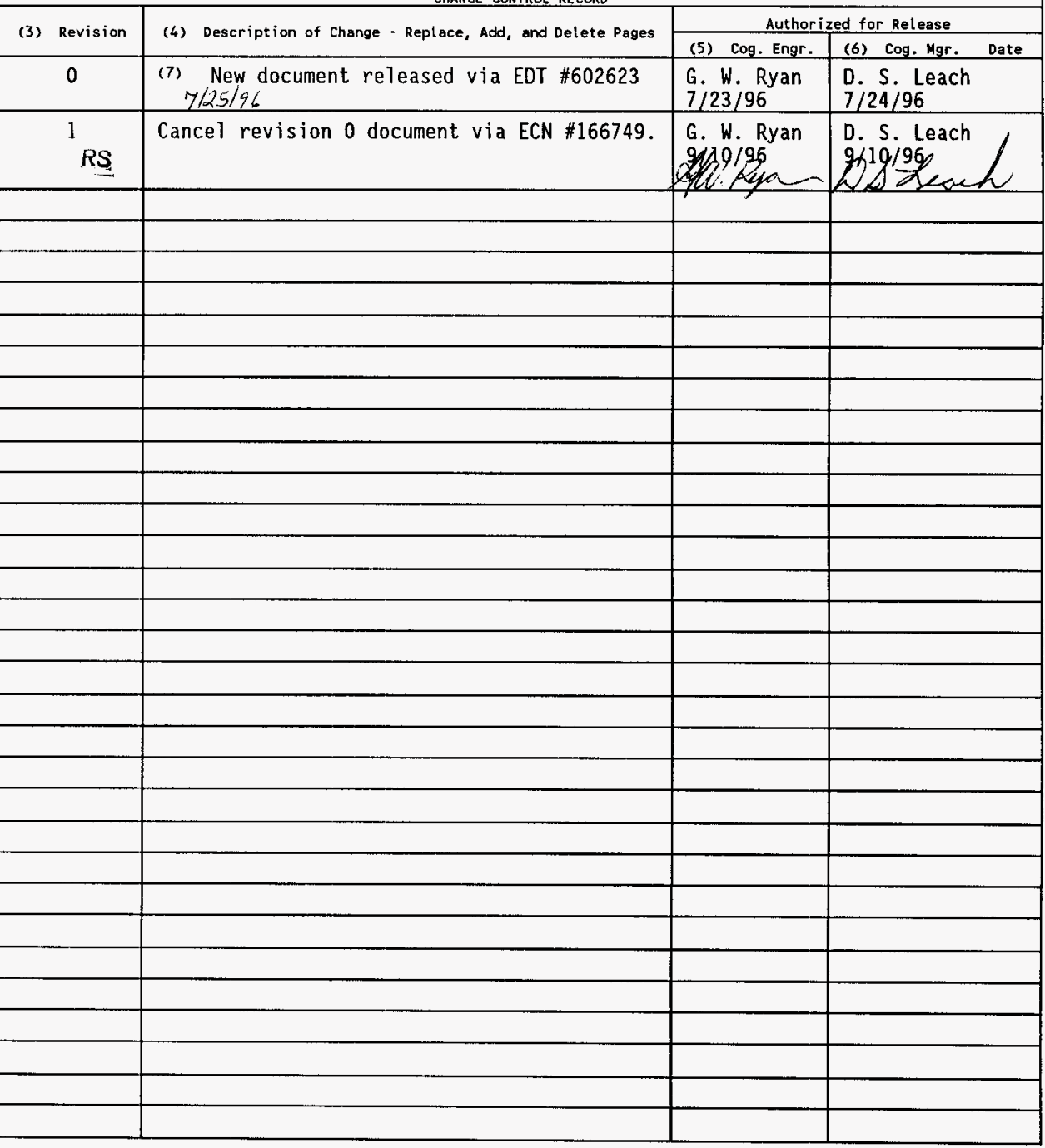




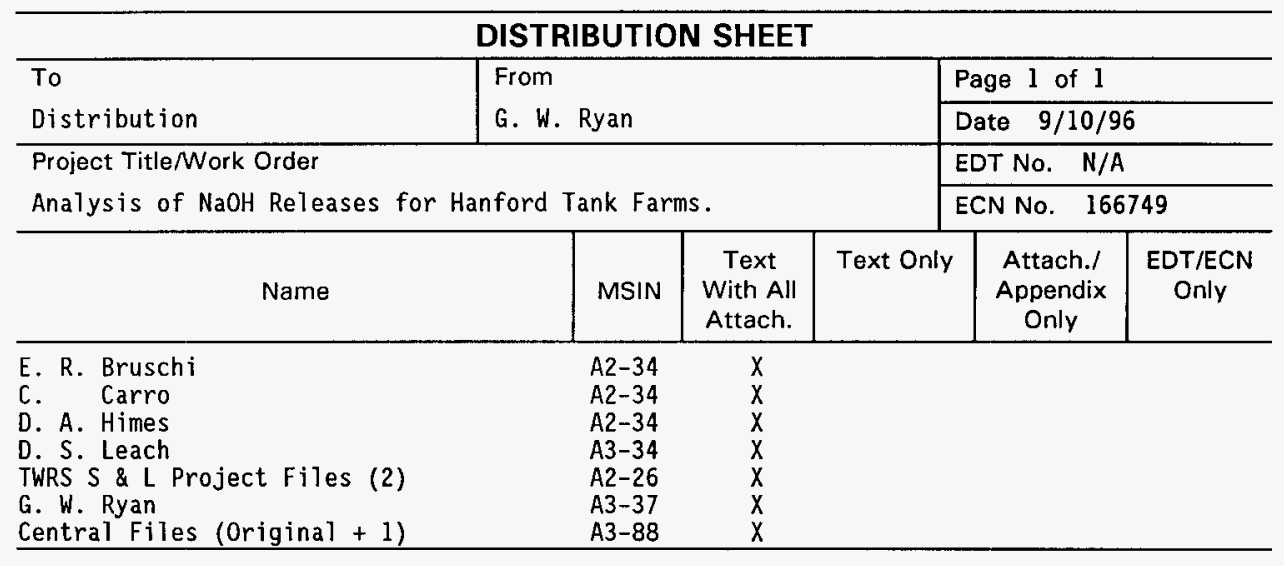

